\title{
Occurrence of fig cryptic virus in fig trees in Iraq
}

\author{
Nabeel Al-Kaeath ${ }^{1,2,3} \cdot$ Manel Elair $^{1} \cdot$ Lehad Arezki $^{4} \cdot$ Naima Mahfoudhi $^{1}$
}

Received: 19 September 2021 / Accepted: 26 October 2021 / Published online: 3 November 2021

(c) Società Italiana di Patologia Vegetale (S.I.Pa.V.) 2021

Keywords Ficus carica $\cdot$ Fig cryptic virus · Iraq

Fig (Ficus carica) belongs to the family Moraceae and is one of the oldest and most important cultivated fruit crops in many countries in temperate regions of the world. The vigor and yield of fig trees are affected by many diseases, the most detrimental of them is fig mosaic disease, which is caused by a complex of viruses. A previous study has shown the presence of fig mosaic virus (FMV) in the northern part of Iraq (Mohmmed et al. 2019), but no information is available about the presence of other viruses associated with the disease. The aim of this study is to conduct a survey of major fig viruses, in particular of fig cryptic virus (FCV), in commercial fig orchards in different fig-growing regions in Iraq. A wide range of foliar symptoms including deformations, mosaic, chlorotic mottling, vein banding and clearing, and chlorotic ringspots, were observed on fig trees. One hundred samples were collected from the most important fig cultivars Aswed Dyala (50 samples), Waziri (35 samples) and Sultani (15 samples), and total nucleic acids were extracted from leaf tissue with the silica capture protocol (Foissac et al. 2001). All samples were tested by RT-PCR for the presence of FCV using a specific primer pair designed in the RNA-dependent RNA polymerase region (Elbeaino et al. 2011) to amplify a genomic fragment of $350 \mathrm{bp}$ in size. Results showed that $45 \%$ (45 of 100) of the tested samples were infected by FCV.

Naima Mahfoudhi

nmahfoudhi@yahoo.fr

1 Laboratoire de Protection des Végétaux, Université de Carthage, Institut National de la Recherche Agronomique de Tunisie, Rue Hedi Karray, 1004 ElMenzah, LR16INRAT04 Tunis, Tunisia

2 Department of Plant Protection, Higher Agronomic Institute of Chott-Mariem. Sousse University, Sousse, Tunisia

3 Department of Plant Protection, College of Agriculture, University of Al-Muthanna, Samawah, Iraq

4 Laboratoire de Phytopathologie et Biologie Moléculaire. Ecole Nationale Supérieure d'Agronomie. Rue Hacen Badi, Belfort, El Harrach, 16000 Alger, Algeria
RT-PCR amplicons of six samples were sequenced and nucleotides sequences were deposited in GenBank under accessions numbers OU452323-OU452328. Iraqi isolates shared $96 \%$ to $100 \%$ nucleotide sequence identity among them, and 96\% to 99\% with FCV isolate BN13 (FR687854) from Italy. Among the other fig viruses selected for this survey, including FMV, fig fleck-associated virus (FFkaV), and fig leaf mottle-associated virus 2 (FLMaV2), only FMV was detected in $37 \%$ ( 37 of 100) of the samples tested. To our knowledge, this is the first report of FCV in fig trees in Iraq.

Data availability The sequencing data generated in this study were deposited in the GenBank and will be freely available to any researcher.

\section{Declarations}

Informed consent All authors have approved the submission of this manuscript.

Conflict of interest The authors declare that they have no conflict of interest.

\section{References}

Elbeaino T, Abou Kubaa R, Digiaro M, Minafra A, Martelli GP (2011) The complete nucleotide sequence and genome organization of Fig cryptic virus, a novel bipartite dsRNA virus infecting fig, widely distributed in the Mediterranean basin. Virus Genes 42:415-421. https://doi.org/10.1007/s11262-011-0581-0

Foissac X, Svanella-Dumas L, Gentit P, Dulucq MJ, Candresse T (2001) Polyvalent detection of fruit tree Tricho, Capillo and Foveaviruses by nested RT-PCR using degenerated and inosine containing primers (PDO RT-PCR). Acta Hortic 550:37-43

Mohmmed RJ, Assie AL, AH, Al Fahad MA (2019) Molecular identification and biological resistance of the fig mosaic virus (FMV) on fig trees in Saladin governorate nurseries. Plant Arch 19:3173-3180

Publisher's Note Springer Nature remains neutral with regard to jurisdictional claims in published maps and institutional affiliations. 